\title{
Recurrent B-Cell Prolymphocytic Leukemia
}

National Cancer Institute

\section{Source}

National Cancer Institute. Recurrent B-Cell Prolymphocytic Leukemia. NCI Thesaurus.

Code C158081.

The reemergence of a B-cell prolymphocytic leukemia after a period of remission. 